\title{
Development of Intestinal Host Defense: An Increased Sensitivity in the Adenylate Cyclase Response to Cholera Toxin in Suckling Rats
}

\author{
JEONG K. SEO ${ }^{1}$, SHU-HEH W. CHU, AND W. ALLAN WALKER \\ The Combined Program in Pediatric Gastroenterology and Nutrition, The Children's Hospital and \\ Massachusetts General Hospital, and Department of Pediatrics, Harvard Medical School, \\ Boston, Massachusetts 02115
}

\begin{abstract}
To determine if developmental variations existed in the second messenger system that mediates cholera toxin (CT) action, the adenylate cyclase (AC) response was studied in 2 -wk-old suckling and 6 -wk-old weaned rats. AC was assayed in the proximal small intestine $4 \mathrm{~h}$ after intraduodenal administration of various doses of CT. Dose-effect analysis showed a 9-fold increase in the sensitivity of the CT-activated cyclase response in suckling rats when measured by the $\mathrm{ED}_{50}$, expressed as $\mu \mathrm{g} \mathrm{CT/g}$ body wt $(0.03$ for $2 \mathrm{wk}, 0.27$ for $6 \mathrm{wk})$. When the CT dose was expressed as $\mu \mathrm{g} / \mathrm{animal}$, suckling rats were 50 times more sensitive than 6-wk-old rats. In addition, the CTinduced fluid secretion was closely correlated with the elevated cyclase activities (correlation coefficient: 0.83 for 2 wk, 0.93 for 6 wk). Furthermore, more fluid seemed to be secreted/unit wt of gut in the sucklings, even when the same level of enzyme activity was compared. A maximum of 3- to 4-fold rise in AC activation occurred at $0.5 \mu \mathrm{g} \mathrm{CT} /$ $\mathrm{g}$ body wt, but both the basal and the maximal stimulated levels of AC were not developmentally different. This study demonstrates an in vivo increase in $\mathrm{AC}$ responsiveness to CT that may be in part responsible for the increased incidence of toxigenic diarrhea in neonates. (Pediatr Res 25:225-227, 1989)
\end{abstract}

Abbreviations

AC, adenylate cyclase

$\mathrm{CT}$, cholera toxin

There has been increasing evidence that the immature epithelial cell and its mucosal surface interaction with bacteria and their enterotoxins may in part account for the noted increased susceptibility of neonates to diarrhea. For example, we have recently shown an increased enterocyte sensitivity to CT-induced fluid secretion in suckling rats (1). A similar increased sensitivity to Escherichia coli heat-stable enterotoxin was reported by Cohen et al. (2). Both cholera toxin and heat-stable enterotoxin are major causes for infectious diarrhea in children, especially in the developing world $(3,4)$.

Received August 26, 1988; accepted October 26, 1988.

Correspondence Shu-heh W. Chu, Ph.D., Combined Program in Pediatric Gastroenterology and Nutrition, Children's Hospital, 300 Longwood Avenue, Boston, MA 02115.

Supported by United States Public Health Service Grants DK37521 and HD12437 from NIH.

${ }^{1}$ Present address Gastroenterology Division, Department of Pediatrics, Seoul National University Hospital, Seoul, Korea.
Cholera toxin is a protein made of 5 binding $B$ subunits and 1 active $A$ subunit (5). It acts by accumulating cAMP in the cell (6-9). After binding of the B subunit to the microvillus membrane receptor, ganglioside $G M 1$, the active $A_{1}$ fragment enters the cell after releasing the $A_{2}$ fragment on the A subunit (10), and presumably travels to the basolateral membrane where intestinal AC is located $(11,12)$. $A_{1}$ catalyzes ADP-ribosylation on the $G_{s}$ subunit of the $A C$ complex $(6-8)$. The covalent modification of the $G_{s}$ unit causes the inhibition of the GTPase and induces a persistent activation of the cyclase to produce cAMP from ATP (6-8). However, not all the steps in this signal pathway leading to the secretory response have been demonstrated in the natural target tissue (i.e. the proximal small intestine). Nor is the responsiveness of $\mathrm{AC}$ to toxin in the developing intestine adequately characterized.

To understand better the role of $\mathrm{AC}$ in neonatal diarrheal disease, we have used suckling rats as an experimental animal model and CT as a toxin probe to study the development of the intestinal host defense. Here we briefly describe an increased enterocyte sensitivity in the $\mathrm{CT}$-activated $\mathrm{AC}$ response in the immature intestine of suckling rats. This observation may provide a developmental-dependent cellular mechanism to help explain the increased susceptibility to toxigenic diarrhea during infancy.

\section{MATERIALS AND METHODS}

Animals. Female Sprague-Dawley rats (CD strain) were purchased from Charles River Breeding Laboratories (Wilmington, $\mathrm{MA})$ at 16-18 d of gestation or after weaning.

Toxin treatment. After an overnight fast, 2-wk-old suckling and 6-wk-old growing rats were anesthetized with ether. Body wt was measured to determine the vol of diluted toxin solution for injection. The abdomen was opened longitudinally. After placing a ligature at the distal duodenum to prevent both influx of the stomach, bile, and pancreatic fluids into the small intestine and the reflux of the CT solution into the stomach, various doses of $\mathrm{CT}$, in a vol of $0.01 \mathrm{ml} / \mathrm{g}$ body wt, were injected into the doudenum just distal to the ligature. The dose solution was prepared in PBS $\left(136 \mathrm{mM} \mathrm{NaCl}, 2.6 \mathrm{mM} \mathrm{KCl}, 8 \mathrm{mM} \mathrm{Na}_{2} \mathrm{HPO}_{4}\right.$, and $1.5 \mathrm{mM} \mathrm{KH} \mathrm{PO}_{4}, \mathrm{pH} 7.3$ ) containing $0.1 \% \mathrm{BSA}$. The abdomen was then closed. Animals were kept in a warm bath to maintain body temperature.

Tissue preparation and fluid measurement. Animals were killed after $4 \mathrm{~h}$ preincubation in vivo with CT. The small intestinal segment was quickly removed from the site of duodenal ligature to the ileocecal valve, with special care not to lose the accumulated intestinal fluid, and was then weighed. The CT. induced net fluid accumulation in the entire small intestine was estimated by subtracting the mean gut wt of control animals 
from the gut wt (including the accumulated fluid) of the toxininjected animals and expressed as per g of gut wt. The small intestine was then divided into a proximal and distal half. After rinsing with ice-cold saline $(0.9 \% \mathrm{NaCl})$, the proximal segment was either placed on ice and the mucosa scraped for enzyme assay immediately or stored at $-70^{\circ} \mathrm{C}$ until analysis.

$A C$ assay. A $6.7 \%$ mucosal homogenate was made in $0.1 \mathrm{M}$ Tris- $\mathrm{HCl}(\mathrm{pH} 7.4)$ containing $10 \mathrm{mM} \mathrm{MgCl}_{2}$ and $1 \mathrm{mM}$ EDTA at $4^{\circ} \mathrm{C}$. The $\mathrm{AC}$ assay was performed at $37^{\circ} \mathrm{C}$ for $10 \mathrm{~min}$ by adding $80 \mu \mathrm{l}$ of mucosal homogenate to $120 \mu \mathrm{l}$ of reaction mixture containing $30 \mathrm{mM}$ Tris- $\mathrm{HCl}(\mathrm{pH} 7.4), 4 \mathrm{mM} \mathrm{MgCl}_{2}, 2$ $\mathrm{mM}$ ATP, $0.1 \mathrm{mM}$ EDTA, $10 \mathrm{mM}$ theophylline, and an ATP. regenerating system that consisted of $10 \mathrm{mM}$ creatine and 0.2 $\mathrm{mg} / \mathrm{ml}$ of creatine phosphokinase. The reaction was terminated by immersing the tubes in boiling water for $3 \mathrm{~min}$. After removal of the precipitate by centrifugation, the supernatant was used to determine cAMP formed, using a cAMP assay kit from Amersham Corporation (Arlington Heights, IL). Protein was determined by the method of Lowry et al. (13) using BSA as the standard. The enzyme activity was expressed as pmol of cAMP formed $/ \mathrm{min} / \mathrm{mg}$ protein.

Statistics. Data were analyzed using a dose-effect analysis program (14), $t$ test, or ANOVA.

\section{RESULTS}

Comparison of 2-wk- and 6-wk-old rats revealed an approximately 5-fold increase in both body wt $(30.1 \pm 4.3$ versus 166.0 $\pm 22.6 \mathrm{~g})$ and the small intestinal wt $(1.2 \pm 0.5$ versus $5.9 \pm 1.0$ g) after weaning. A 2 -fold difference in the intestinal length (45.0 \pm 1.6 versus $92.4 \pm 7.6 \mathrm{~cm}$ ) presumably was accompanied by an increased cross-section of the gut (15). Both body wt and intestinal wt were used to calculate the toxin dose and the toxininduced secretory response in this study to quantitate the doseeffect relationship.

Table 1 compared the activity of $\mathrm{AC}$ with and without toxin stimulation in 2- and 6-wk-old rats. Both fresh and frozen samples exhibited an approximately 3 - to 4-fold rise in the toxininduced cyclase activity. However, the frozen samples lost a great amount (about $80 \%$ ) of enzyme activity. Subsequently, all the enzyme data reported in this study were assayed using fresh gut samples immediately after animals were killed. We also found that the maximal CT-activated cyclase response was about 0.5 $\mu \mathrm{g}$ of toxin/g body wt for both age groups. Death occurred in the fasted suckling rats when the injected toxin dose was increased by 3 -fold, but not in the fasted postweaned rats. Table 1 also shows that there were no age differences in the basal and the maximal stimulated levels of $\mathrm{AC}$ activities between these 2 groups. Similar results were noted in the subsequent dose-response study (Fig. 1).

As shown in Figure 1, the response of AC to CT stimulation occurred in a dose-dependent manner. An age difference was

Table 1. Basal and maximal levels of adenylate cyclase activities stimulated by $C T$ in proximal small intestine of pre( 2 wk old) and postweaned (6 wk old) rats*

\begin{tabular}{|c|c|c|c|}
\hline \multirow{2}{*}{ Mucosal homogenate } & \multirow{2}{*}{$\begin{array}{l}\text { Toxin dose } \\
(\mu \mathrm{g} / \mathrm{g} \\
\text { body wt })\end{array}$} & \multicolumn{2}{|c|}{$\begin{array}{c}\text { AC activity } \\
\text { (pmol cAMP } / \mathrm{min} / \mathrm{mg} \text { protein) }\end{array}$} \\
\hline & & $2 \mathrm{wk}$ & $6 \mathrm{wk}$ \\
\hline $\begin{array}{l}\text { Frozen gut } \\
\left(-70^{\circ} \mathrm{C}, 1-3 \mathrm{~d}\right) \\
\text { Fresh gut }\end{array}$ & $\begin{array}{l}0 \\
0.5 \\
0 \\
0.5\end{array}$ & $\begin{array}{r}0.82 \pm 0.13(8) \\
3.44 \pm 0.45(8) \\
5.71 \pm 0.20(4) \\
15.67 \pm 0.88(2)\end{array}$ & $\begin{array}{r}0.97 \pm 0.12(8) \\
3.52 \pm 0.42(8) \\
5.72 \pm 0.47(6) \\
14.42 \pm 1.17(2)\end{array}$ \\
\hline
\end{tabular}

* The small intestine was exposed to CT in vivo for $4 \mathrm{~h}$. Values are means $\pm \mathrm{SD}$ for the number of samples (one gut/sample) indicated in parentheses. ANOVA indicates that there are significant differences $(p<0.001)$ in the level of enzyme activity due to toxin treatment, but not age effect.

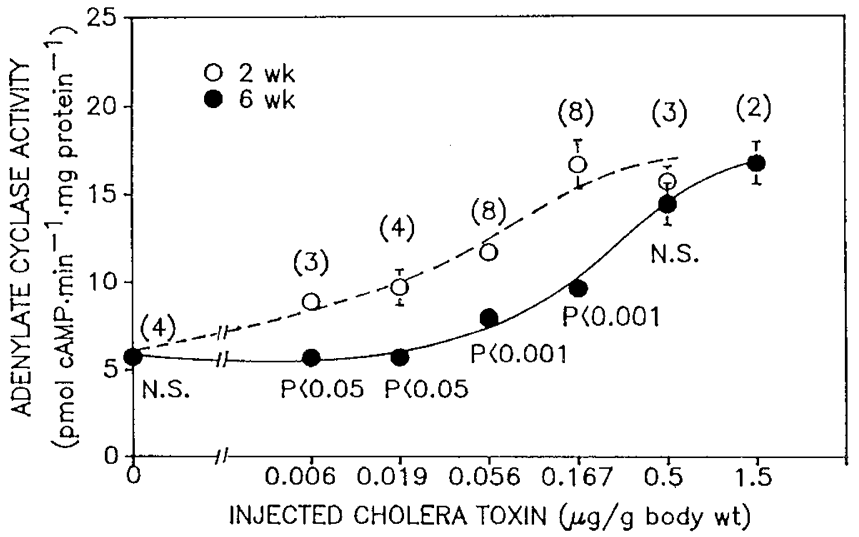

Fig. 1. Dose-response curves for $\mathrm{CT}$-induced $\mathrm{AC}$ activation in the proximal small intestine of 2-wk- and 6-wk-old rats. AC was assayed in mucosal homogenates prepared from fresh guts (one gut/sample) after 4 $\mathrm{h}$ in vivo preincubation with toxin. Each point represents a mean $\pm \mathrm{SD}$ for the number of samples as indicated in parentheses. The significant level ( $p$ value) for each toxin dose is as indicated.

noted in the dose-response curve, with a shift of the curve in the 2-wk-old group to the left of the 6-wk group. The ED $\mathrm{ED}_{50}$ was calculated from these dose-response curves to be $0.03 \mu \mathrm{g} \mathrm{CT} / \mathrm{g}$ body wt for 2 -wk-old and $0.27 \mu \mathrm{g} \mathrm{CT} / \mathrm{g}$ body wt for 6 -wk-old rats, suggesting a 9-fold increase in the sensitivity to $\mathrm{CT}$ in the suckling rats. When $\mathrm{ED}_{50}$ was expressed as $\mu \mathrm{g} \mathrm{CT} /$ animal, there was a 50 -fold increase in the sensitivity to $\mathrm{CT}$ in the suckling rats $(0.89$ for 2 -wk-old and 44.11 for 6 -wk-old rats).

The relationship of fluid secretion to AC activity induced by $\mathrm{CT}$ is shown in Figure 2. The secretory response correlated well with the stimulated level of AC activity in both age groups. In addition, the slopes of the two linear regression lines were different. The 2-wk-old group had a steeper slope than the 6-wk-old group had when the fluid accumulation was expressed per unit of gut wt.

\section{DISCUSSION}

The in vivo activation of $\mathrm{AC}$ after intraduodenal administration of CT in an intact rat represents a net result of the coupling of receptor binding to the cellular effector system. The activated $\mathrm{AC}$ then causes elevation of cAMP which transmits the toxin signal for the inhibition of $\mathrm{NaCl}$ uptake and the stimulation of $\mathrm{Cl}^{-}$secretion, resulting in net fluid secretion (16).

An increased sensitivity of the AC response was noted by a quantitative dose-effect analysis. The cyclase response in an individual 2-wk-old sucking rat was 50 times more sensitive than that of the 6-wk-old animal when exposed to the same quantity of CT. By contrast, when the small intestine was exposed to an equal amount of toxin on the basis of body mass, the cyclase response was nine times more sensitive in the 2 -wk-old than in the 6-wk-old rat.

Developmental changes in the responsiveness of AC to CT did not seem to be due to variations in the catalytic unit of the $\mathrm{AC}$ complex as the basal and maximal stimulated activities were not different between the pre- and postweaned rats. Nor was it related to the binding of $\mathrm{CT}$ to the mucosal membrane receptor, GM1, because we have previously shown that the increased host sensitivity in the secretory response of suckling rats was independent of the receptor occupancy (1).

Increased sensitivity to toxin in the suckling rat might be associated with variations in the efficiency of toxin entry and/or translocation to the target site, or variations in amounts and functions of the regulatory GTP-binding proteins during intestinal development. Recently, Dominquez et al. (17) have reported that the brush border membrane of the rabbit intestine contains regulatory subunits of $\mathrm{AC}$; they suggested an alternative 


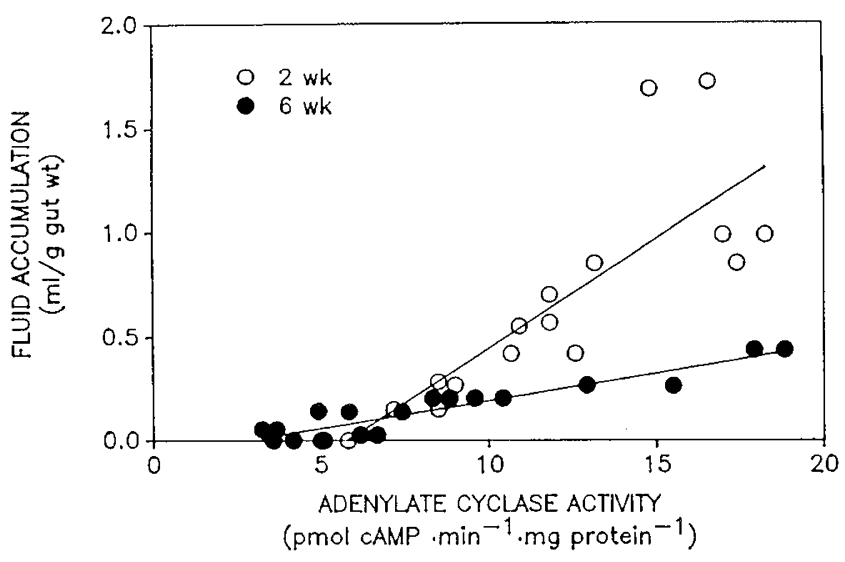

Fig. 2. The relationship between $C T$-induced $A C$ and fluid secretion in the small intestine of 2-wk- and 6-wk-old rats. Each point represents the data obtained from an individual rat. The calculated linear regression equations are: $\mathrm{Y}=0.10 \mathrm{X}-0.60(r=0.83)$ for $2 \mathrm{wk}$; and $\mathrm{Y}=0.03 \mathrm{X}$ $-0.07(r=0.93)$ for $6 \mathrm{wk}$. Here $\mathrm{Y}$ is fluid accumulation: $\mathrm{X}$ is $\mathrm{AC}$ activity.

mechanism for signal transduction of toxin action, without $\mathrm{A}_{1}$ subunit translocation to the basolateral membrane. Thus far, ADP-ribosylation of $\mathrm{G}$ proteins by activated $\mathrm{CT}$ has not been demonstrated in the rat intestine in vitro. Further studies of the nature of toxin transport and $G$ protein activities as well as their developmental regulation in the rat intestine are needed to explain the increased sensitivity of the cyclase response noted in this study.

Our data also indicate that there was an age-related difference in post-AC steps for the toxin-induced secretory response. It appeared that the increase of a given unit of the activated cyclase activity tended to cause a greater amount of fluid secretion/unit wt of gut in the sucklings than in the older animals (see Fig. 2). There are some indications that CT may act by cAMP-independent mediators such as calcium (18) and other neural factors (19). It remains to be determined whether the additional increase in fluid secretion by the immature gut is due to variations in the cAMP-dependent ion flux or to other CT-dose-dependent, cAMP-independent events within the enterocyte.

In conclusion, this study provides in vivo evidence that developmental changes in a second messenger system occurred in the pathophysiologic pathway of CT. The increased sensitivity in AC responsiveness may be in part responsible for the high incidence of toxigenic diarrhea in neonates.

\section{REFERENCES}

1. Chu SW, Ely IG, Walker WA 1989 Age and cortisone alter host responsiveness to cholera toxin in the developing gut. Am J Physiol 256:G220-G225

2. Cohen MB, Moyer MS, Luttrell M, Giannella RA 1986 The immature rat small intestine exhibits an increased sensitivity and response to Escherichia coli heat-stable enterotxoin. Pediatr Res 20:555-560

3. Black RE, Brown KH, Becker S, Alim AR, Hug I 1982 Longitudinal studies of infectious diseases and physical growth in rural Bangladesh: II. Incidence of diarrhea and association with known pathogens. Am $\mathrm{J}$ Epidemiol $115: 313-324$

4. Snyder JD, Merson MH 1982 The magnitude of the global problem of acute diarrhoeal disease: a review of active surveillance data. Bull WHO 60:605613

5. Gill DM 1976 The arrangement of subunits in cholera toxin. Biochemistry 15:1242-1248

6. Cassel D, Pfeuffer T 1978 Mechanism of cholera toxin action: covalent modification of the guanyl nucleotide-binding protein of the adenylate cyclase system. Proc Natl Acad Sci USA 75:2669-2673

7. Gill DM, Meren R 1978 ADP ribosylation of membrane proteins catalyzed by cholera toxin: basis of the activation of adenylate cyclase. Proc Natl Acad Sci USA 75:3050-3054

8. Ross EM, Gilman AG 1980 Biochemical properties of hormone-sensitive adenylate cyclase. Annu Rev Biochem 49:533-564

9. Middlebrook JL, Dorlan RB 1984 Bacterial toxins: cellular mechanisms of action. Microbiol Rev 48:199-221

10. Eidels L, Proia RL, Har DA 1983 Membrane receptors for bacterial toxins. Microbiol Rev 47:596-620

11. Quill H, Weiser MM 1975 Adenylate and guanylate cyclase activities and cellular differentiation in rat small intestine. Gastroenterology 69:470-478

12. Murer H, Ammann E, Biber J, Hopfer V 1976 The surface membrane of the small intestinal epithelial cell: I: localization of adenyl cyclase. Biochim Biophys Acta 433:509-519

13. Lowry OH, Rosebrough NJ, Farr AL, Randall RJ 1951 Protein measurement with the Folin phenol reagent. J Biol Chem 193:265-275

14. Chou TC, Talalay P 1984 Quantitative analysis of dose-effect relationship: the combined effect of multiple drugs or enzyme inhibitors. Adv Enzyme Regul 22:27-55

15. Koldovsky O 1969 Changes in the morphological structure of the small intestine of mammals during development. In: Koldovsky $\mathrm{O}$ (ed) Development of the Functions of the Small Intestine in Mammals and Man. S. Karger AG, New York, pp 1-19

16. Field M 1979 Intracellular mediators of secretion in the small intestine. In: Binder HJ (ed), Mechanisms of Intestinal Secretion. Liss, New York, pp 8391

17. Dominquez P, Velasco G, Barros F, Lazo PS 1987 Intestinal brush border membranes contain regulatory subunits of adenylyl cyclase. Proc Natl Acad Sci USA 84:6965-6969

18. Roomi N, Laburthe M, Fleming N, Crowther R, Forstner J 1984 Cholerainduced mucin secretion from rat intestine: lack of effect of cAMP, cycloheximide, VIP, and colchicine. Am J Physiol 247:G140-G148

19. Cassuto J, Siewert A, Jodal M, Lundgren O 1983 The involvement of intramural nerves in cholera toxin induced intestinal secretion. Acta Physiol Scand 117:195-202 